УДК 351.777

DOI: https://doi.org/10.26642/jen-2019-3(89)-191-200

\author{
Л.В. Сергіснко, к.держ.упр. \\ О.М. Дзюбенко, к.е.н. \\ Державний університет «Житомирська політехніка» \\ C.В. Ожго, магістрант \\ Департамент фінансів \\ Житомирської обласної державної адміністрації
}

\title{
Державна екологічна політика України та правовий механізм ії формування і реалізації
}

\begin{abstract}
Ідентифіковано стратегічні цілі державної екологічної політики, щуо задекларовані в офіиійних документах України за період ї̈ незалежності, в результаті яких охарактеризовано вектори державної екологічної політики та встановлено їх конкретизацію, щзо свідчить не лише про загострення екологічних проблем, а і усвідомлення їх владою у процесі здійснення державноуправлінської діяльності. На охорону, раціональне використання та відтворення природних ресурсів, ефективне поєднання функиій природокористування та охорони навколишнього природного середовища, забезпечення екологічно безпечного існування нинішнього та майбутніх поколінь суттєво впливає система державного управління. Цей вплив здійснюється через механізми державного екологічного управління та, відповідно, механізми формування та реалізації екологічної політики. Встановлено, щзо правовий механізм є основою державного управління у сфері реалізації екологічної політики, який має забезпечувати реалізацію науково обтрунтованих принципів охорони навколишнього природного середовища, раціонального використання природних ресурсів і екологічну безпеку життєдіяльності людей, встановлювати науково обтрунтовані правила поведінки людей, підприємств $і$ організацій у галузі екології. Формування та реалізачія державної екологічної політики нерозривно пов'язана із процесами формування та реалізації відповідної політики на наднаціональному та суб'єктному рівнях, зокрема в частині використання правового регулювання як інструменту політики та основи ії правового механізму. Побудова правового механізму формування та реалізації екологічноі політики із деталізацією інструментів правового регулювання у розрізі рівнів політики дозволила встановити взаємозв'язки між рівнями, визначити зміст иієї взаємодії. Ідентифіковано та охарактеризовано критерії взаємодї деталізованих інструментів правового регулювання між рівнями політики.
\end{abstract}

Ключові слова: екологічна безпека; екологічна політика; правовий механізм екологічної політики; державне екологічне управління.

Постановка проблеми. Людина - невіддільна складова природи, яка володіє певними екологічними правами та, відповідно, має екологічні обов'язки. Насамперед це пріоритетне право на здорове та гармонійне довкілля. Тому питання безпечного та якісного природного навколишнього середовища $\epsilon$ фундаментальними для західної цивілізації, частиною якої є й Україна.

Тим не менше, основні показники техногенного навантаження на навколишнє природне середовище та витрат на природоохоронні заходи в Україні свідчать про погіршення стану довкілля як життєво важливого середовища для існування людини та складової частини національної безпеки країни. Така ситуація пов'язана з тим, що впродовж тривалого часу перевага надавалася розвитку сировинновидобувних, найбільш екологічно небезпечних, галузей промисловості, а також з відсутністю необхідних обсягів інвестицій для оновлення технологій та здійснення природоохоронних заходів.

Екологічну політику здійснює держава, яка, однак, не є єдиним суб'єктом екологічної політики. Поряд з державою екологічну політику реалізують політичні гравці - партії, політики, громадські організації та органи місцевого самоврядування, інші суб'єкти, що робить іiі об'єктом не лише державного, але й публічного управління.

Тим не менше, саме держава як основний інститут політичної системи за допомогою сукупності методів, засобів та інструментів в особі органів державної влади, у межах їх компетенції відіграє провідну роль в еколого-економічних відносинах суспільства. Все сказане вище актуалізує вивчення сутності екологічної політики, насамперед - державної, і особливостей державного екологічного управління.

Аналіз останніх досліджень і публікацій. Проблеми екологічної політики: в контексті теоретичних та практичних засад удосконалення державного управління розглянуті у роботах, Т.Галушкіної, М.Грановської, Т.Іванової, О.Лазора, В.Лук'янихіна; з позицій регіонального та державного управління досліджували А.Голіков, В.Керецман, О.Куценко, В.Лісничий, Н.Нижник, В.Рехкал, С.Романюк, 
В.Тертичко, М.Томенко; питанню державотворення в контексті взаємозв'язку сталого розвитку, глобалізації та трансформації економіки присвячені роботи О.Білорус, О.Врублевської, Г.Дзяни, М.Згуровського, О.Осауленко, А.Романовича, Л.Сергієнко, І.Синякевича, Т.Туниці, А.Урсула, Є.Хлобистова та ін.

Метою статті є визначення особливостей державної екологічної політики у сучасних умовах та побудова правового механізму їі формування та реалізації.

Викладення основного матеріалу. Державна політика $\epsilon$ невід'ємним елементом системи державного управління, яку ототожнюють 3 мистецтвом управління державою та суспільством. 3 позицій здійснення державно-управлінського впливу у конкретній сфері, державна політика визначає позицію державних владних структур щодо вибору варіантів вирішення суспільних проблем, а також методів та інструментів реалізації відповідних політичних рішень. Поняття «державна політика» не $\epsilon$ новим та широко застосовується у всіх сферах суспільної організації, де виникає потреба у збалансуванні інтересів членів суспільства/іх окремих груп. Звідси, можна стверджувати, що першочергове завдання політики це досягнення суспільного балансу інтересів стейкхолдерів відповідної сфери політики. В свою чергу, залежно від домінуючої доктрини, пошук балансу інтересів базуватиметься на принципах та здійснюватиметься у межах відповідного системоутворюючого вчення. Поява концепцій розвитку та їх домінування у конкретному періоді $є$ наслідком існування проблем у тій чи іншій сфері суспільного життя, тобто це відповідь на: неефективність певних державно-управлінських дій; неможливість вирішення таких проблем шляхом продовження реалізації тієї самої політики; появу нових об’єктів/проблем, що потребують врегулювання/вирішення у межах системи державного управління. Зважаючи на сукупність чинників, що обумовлюють процес формування та реалізації державної політики в цілому, а також визначають цілі політики відповідно до особливостей та вимог зовнішнього та внутрішнього середовища у конкретному періоді, доцільно розкрити сутність державної екологічної політики 3 метою побудови правового механізму іiі формування та реалізації, а також ідентифікації взаємозв'язків між елементами цього механізму.

Аналіз літературних джерел дозволяє стверджувати про відсутність єдиного підходу щодо трактування державної екологічної політики (табл. 1).

Табличя 1

Визначення сутності поняття «державна екологічна політика»

\begin{tabular}{|c|c|}
\hline Автор, джерело & Підхід до визначення сутності \\
\hline $\begin{array}{c}\text { М.В. Андрієнко, } \\
\text { В.С. Шако [1] }\end{array}$ & $\begin{array}{l}\text { Складова політики держави, що відображає сукупність їі цілей і завдань у сфері } \\
\text { екології, які формуються політичною системою держави відповідно до ііі } \\
\text { соціального призначення і реалізуються нею за допомогою певних механізмів }\end{array}$ \\
\hline Н.А. Малиш [13] & $\begin{array}{l}\text { Сукупність засобів і заходів, пов’язаних із впливом суспільства на природу, } \\
\text { спрямованих на забезпечення екологічно збалансованого розвитку і } \\
\text { цивілізованості. Екологічну політику треба розуміти як координуючу } \\
\text { першооснову, яка формує і приводить у рух ресурси підприємства (організації), } \\
\text { для досягнення цілей у сфері раціонального природокористування, охорони } \\
\text { навколишнього середовища і забезпечення екологічної безпеки за допомогою } \\
\text { політичних, економічних, юридичних, освітніх та інших заходів }\end{array}$ \\
\hline $\begin{array}{c}\text { В.Г. Сахаєв, } \\
\text { В.Я. Шевчук [17] }\end{array}$ & $\begin{array}{l}\text { Розробка пріоритетів на перспективу з урахуванням здоров’я населення і } \\
\text { збільшення тривалості життя, відтворення рослинного і тваринного світу, } \\
\text { збереження екологічного, генетичного і матеріального базису, природної, } \\
\text { історичної спадщини і культури }\end{array}$ \\
\hline О.П. Мягченко [15] & $\begin{array}{l}\text { Система заходів, пов'язаних із запобіганням негативним впливам суспільства } \\
\text { на природу }\end{array}$ \\
\hline Д.О. Ветвицький [2] & $\begin{array}{l}\text { Комплекс засобів і заходів, спрямованих державою на охорону та оздоровлення } \\
\text { довкілля, ефективне поєднання природокористування і природоохорони та } \\
\text { забезпечення нормальної життєдіяльності громадян, який має два виміри - } \\
\text { нормативний і регуляційний }\end{array}$ \\
\hline
\end{tabular}

Аналіз визначень сутності поняття «державна екологічна політика», що наведено в таблиці 1 , дозволяє стверджувати, що державна екологічна політика є комплексом законодавчо визначених цілей i завдань, засобів та інструментів, заходів та дій органів державної влади на всіх рівнях у сфері екології та охорони навколишнього середовища, що спрямовані на збереження і відтворення, а також охорону навколишнього природного середовища, максимально ефективне використання природно-ресурсного потенціалу країни, забезпечення раціонального, екологічно безпечного господарювання та високоефективного збалансованого природокористування шляхом запровадження інноваційних та 
екологічних технологій, створення сприятливих умов для забезпечення екологічної безпеки держави та безпечного життя іiі громадян.

Об'єктом екологічної політики є екологічне та навколишнє середовище, тобто сукупність природних і соціальних процесів, природні ресурси, здоров'я та життя людей. Основним суб'єктом реалізації державної екологічної політики є держава, що ініціює формування та реалізацію державної політики в особі органів державної влади разом із громадянським суспільством, що неодмінно, в демократичних умовах, має долучатися до процесу прийняття та здійснення державно-управлінських рішень. На сучасному етапі розвитку в Україні відбуваються процеси реформування системи державного управління, основною метою яких є підвищення спроможності центральних органів виконавчої влади, тобто трансформація міністерств у аналітично-владні центри, функціонування яких полягатиме у постійному аналізі проблем та пошуку можливих варіантів їх вирішення, формуванні та реалізації відповідних політик, а також оцінці ймовірних чи наявних наслідків реалізації цих політик. Таким чином, відповідно до основних змін, що передбачає сучасний процес реформування системи державного управління, до функцій міністерств належать формування та реалізацію державної політики на засадах аналізу політики як системного процесу, що полягає у здійсненні постійного моніторингу стану вирішення проблем, та оцінці ситуації у відповідній сфері управління/регулювання та оперативного реагування на можливі наслідки впроваджених державно-управлінських рішень. На сьогодні, основним суб'єктом формування та реалізації державної екологічної політики в Україні є Міністерство екології та природних ресурсів. Відповідно до даних щодо місії та стратегії Міністерства екології та природних ресурсів, що наведені на офіційному веб-сайті державного органу [14], у межах абсолютно усіх напрямів діяльності міністерство виконує функцію забезпечення нормативно-правового регулювання 3 питань, що належать до відповідної сфери діяльності органу, а також «розробляє та подає на розгляд Президентові України та Кабінету Міністрів України проекти законів України, актів Президента України, Кабінету Міністрів України; готує в межах повноважень висновки і пропозиції до проектів законів, інших актів законодавства, які надходять для погодження від інших органів; узагальнює практику застосування законодавства, розробляє пропозицій щодо його вдосконалення та вносить в установленому порядку проекти законодавчих актів, актів Президента України, Кабінету Міністрів України на розгляд Президентові України і Кабінету Міністрів України».

Розуміння сутності державної екологічної політики як інструменту організації, регулювання, узгодження та збалансування екологічних та соціально-економічних інтересів суспільства дає можливість спрямувати й ефективно регулювати за допомогою правових засобів державну екологічну діяльність, і це вимагає поглибленої уваги до нормативно-правового забезпечення державної екологічної політики. Більш того, особливістю держави як політичного інституту є прерогатива на використання правових норм (створення, впровадження, реалізація і контроль за їх дотриманням).

Правове регулювання є одним із найважливіших і невід'ємних інструментів державної політики, адже саме цей інструмент дозволяє фактично застосовувати інші інструменти державної політики шляхом їх офіційного декларування та прийняття у вигляді окремих нормативно-правових актів/окремих положень та засад у законодавчих документах.

Фундаментальною основою нормативно-правової бази державної екологічної політики є Конституція України. Саме Конституцією [10] передбачено обов'язок держави - «забезпечення екологічної безпеки і підтримання екологічної рівноваги на території України, подолання наслідків Чорнобильської катастрофи - катастрофи планетарного масштабу, збереження генофонду Українського народу» (стаття 16); «право кожного громадянина на безпечне для життя і здоров'я довкілля та на відшкодування завданої порушенням цього права шкоди, право вільного доступу до інформації, яка ніким не може бути засекречена, про стан довкілля, про якість харчових продуктів і предметів побуту, а також право на іiі поширення» (стаття 50); закріплено «обов'язок кожного громадянина не заподіювати шкоду природі, культурній спадщині, відшкодовувати завдані ним збитки. У Конституції України визначено, що одним із повноважень Верховної Ради України є обов'язок дбати про охорону довкілля, визначати екологічну політику держави, яку реалізує Уряд України» (стаття 60). Сфера екології та охорони навколишнього середовища 3 позицій державного управління є достатньо об'ємною, що обумовлює розгалуженість системи нормативно-правових актів, які забезпечуватимуть з одного боку, регулювання/управління у цій сфері за ключовими напрями, а з другого - обумовлюватимуть правовий механізм формування та реалізації державної екологічної політики, у тому числі і в контексті пріоритетних векторів.

Васюта О.А. [1] зазначає, що «завдання державної екологічної політики повинні мати глобальний стратегічний характер, і найближчим часом набути подвійної спрямованості. 3 одного боку, сучасні методики та технології щодо вдосконалення, як мінімум, мають подолати сучасні негативні тенденції розвитку виробничого комплексу країни в напрямі зменшення ресурсо- та енерговитрат. А 3 другого боку, необхідно створити і забезпечувати таку систему екологічного менеджменту, яка б не давала можливості посилювати техногенне навантаження на довкілля». 
Стратегічні завдання та пріоритети держави, що визначають основоположні засади державної екологічної політики, а також включають визначений світовою спільнотою порядок дій щодо вирішення проблем та поліпшення ситуації в екологічній сфері, викладені у відповідних законодавчих документах стратегіях екологічної політики на визначений період.

3 часу проголошення Україною незалежності прийнято три стратегічні документи щодо визначення державної екологічної політики в Україні. Стратегії державної екологічної політики в Україні та задекларовані у них цілі наведено в таблиці 2.

Таблиияя 2

Стратегії державної екологічної політики в Україні: визначення изілей політики

\begin{tabular}{|c|c|c|}
\hline $\begin{array}{c}\text { Рік } \\
\text { прийняття }\end{array}$ & $\begin{array}{c}\text { Назва законодавчого } \\
\text { документа }\end{array}$ & Цілі державної екологічної політики \\
\hline 1998 & $\begin{array}{lr}\text { Постанова } & \text { Верховної ради } \\
\text { України } & \text { «ро Основні } \\
\text { напрями } & \text { державної } \\
\text { політики } & \text { України у галузі } \\
\text { охорони } & \text { довкілля, } \\
\text { використання } & \text { природних } \\
\text { ресурсів та забезпечення } \\
\text { екологічної безпеки [16] }\end{array}$ & $\begin{array}{l}\text { Проведення інституційної реформи державної системи } \\
\text { охорони довкілля та використання природних ресурсів, } \\
\text { упровадження механізмів та інструментів екологічної } \\
\text { політики, реалізація пріоритетних національних і } \\
\text { державних програм з метою створення умов для сталого } \\
\text { збалансованого розвитку держави; формування державної } \\
\text { системи регулювання екологічної безпеки як неодмінної } \\
\text { складової національної безпеки України }\end{array}$ \\
\hline 2010 & 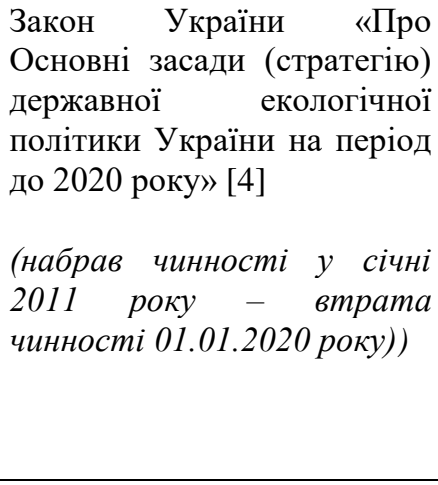 & $\begin{array}{l}\text { Підвищення рівня суспільної екологічної свідомості. } \\
\text { Поліпшення екологічної ситуації та підвищення рівня } \\
\text { екологічної безпеки. } \\
\text { Досягнення безпечного для здоров’я людини стану } \\
\text { навколишнього природного середовища. } \\
\text { Інтеграція екологічної політики та вдосконалення системи } \\
\text { інтегрованого екологічного управління. } \\
\text { Припинення втрат біологічного та ландшафтного } \\
\text { різноманіття і формування екологічної мережі. } \\
\text { Забезпечення зболансованого } \\
\text { природокористування. } \\
\text { Удосконалення регіональної екологічної політики } \\
\end{array}$ \\
\hline 2019 & 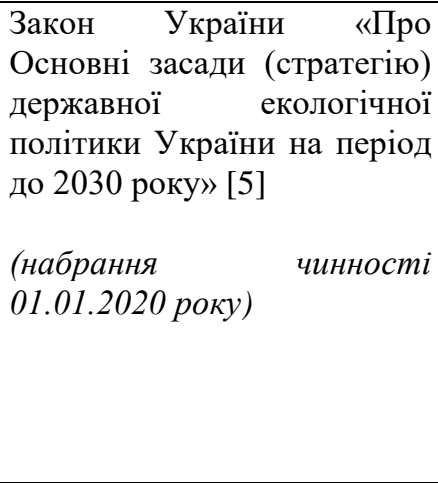 & $\begin{array}{l}\text { Формування в суспільстві екологічних цінностей і засад } \\
\text { сталого споживання та виробництва. } \\
\text { Забезпечення сталого розвитку природно-ресурсного } \\
\text { потенціалу України. } \\
\text { Забезпечення інтеграції екологічної політики у процес } \\
\text { прийняття рішень щодо соціально-економічного розвитку } \\
\text { України. } \\
\text { Зниження екологічних ризиків } 3 \text { метою мінімізації їх } \\
\text { впливу на екосистеми, соціально-економічний розвиток та } \\
\text { здоров'я населення. тазов } \\
\text { Удосконалення та розвиток державної системи } \\
\text { природоохоронного управління }\end{array}$ \\
\hline
\end{tabular}

Слід зазначити, що еволюція цілей державної екологічної політики в Україні (за часів незалежності), що прослідковується у стратегічних документах (табл. 2), свідчить не лише про зміну векторів політики, а їх конкретизацію: від «створення умов для сталого збалансованого розвитку» та «формування системи регулювання екологічної безпеки як складової національної безпеки» до «підвищення рівня екологічної свідомості суспільства» та до «формування в суспільстві екологічних цінностей і засад сталого споживання та виробництва», «удосконалення та розвиток державної системи природоохоронного управління». 3 огляду на цілі державної екологічної політики, задекларовані відповідно в стратегіях 1998, 2010 та 2019 років, можна стверджувати про нагальність екологічних питань у системі державного управління та підвищення уваги з боку держави щодо визначення, деталізації, аналізу та вибору альтернативних варіантів вирішення посталих екологічних проблем. Таким чином, екологічна політика поступово набуває ознак повноцінної державної політики та відповідної сфери державного управління, де держава не просто декларує загальні цілі, а визначає завдання за відповідними напрямами задля можливості проведення моніторингу ефективності державно-управлінських рішень та, за необхідності, подальшого їх коригування. 
Законом України «Про Основні засади (стратегію) державної екологічної політики України на період до 2030 року» [5] визначено, що одним із інструментів державної екологічної політики в Україні $\epsilon$ «законодавство України у сфері охорони навколишнього природного середовища, яке адаптоване до законодавства Свропейського Союзу, спрямоване на досягнення національних пріоритетів та забезпечення його наближення до відповідних директив Європейського Союзу впровадження багатосторонніх екологічних угод (конвенцій, протоколів тощо), стороною яких є Україна». Адже нормативно-правова база в екологічній сфері, що адаптована до вимог Європейського Союзу, $є$ важливою запорукою пришвидшення процесу інтеграції України до європейської спільноти.

Поряд з цим стрижневим документом, який визначає засади державної екологічної політики в Україні, є Закон України «Про охорону навколишнього природного середовища» від 25 червня 1991 року № 1264-XII. Він проголошує та запроваджує систему управління в галузі природокористування. У ньому визначено, що наша держава здійснює на своїй території екологічну політику, спрямовану на збереження безпечного для існування живої і неживої природи навколишнього середовища, захист життя і здоров'я населення від негативного впливу, зумовленого забрудненням навколишнього природного середовища, досягнення гармонійної взаємодії суспільства i природи, охорону, раціональне використання i відтворення природних ресурсів [6].

Основою екологічного права є також ресурсові кодекси: Водний кодекс України забезпечує правову охорону вод від засмічення, забруднення, вичерпання і регулює порядок їх використання [3]; Земельний кодекс України, який регулює охорону і раціональне використання земель [7]; Кодекс України про надра забезпечує раціональне, комплексне використання надр для задоволення потреб суспільства, їх охорону, гарантуючи при цьому безпеку людей та довкілля при користуванні надрами [8]; Кодекс цивільного захисту України регулює відносини, пов'язані із захистом населення, територій, навколишнього природного середовища та майна від надзвичайних ситуацій [9]; Лісовий кодекс України охоплює питання збереження, відновлення та раціонального використання лісів [12].

Природоохоронне законодавство доповнюють закони України «Про охорону атмосферного повітря», «Про тваринний світ», «Про рослинний світ», «Про аквакультуру», «Про природно-заповідний фонд України», «Про охорону земель», «Про державний контроль за використанням та охороною земель», «Про відходи», «Про екологічну мережу України», «Про затвердження Загальнодержавної цільової програми розвитку водного господарства та екологічного оздоровлення басейну річки Дніпро на період до 2021 року», «Про забезпечення санітарного та епідемічного благополуччя населення», «Про зону надзвичайної екологічної ситуації», «Про правовий режим території, що зазнала радіоактивного забруднення внаслідок Чорнобильської катастрофи», «Про статус і соціальний захист громадян, що постраждали внаслідок Чорнобильської катастрофи». Врешті, підзаконні нормативно-правові акти загальнодержавного значення у сфері охорони навколишнього середовища та раціонального використання природних ресурсів розмежовують повноваження між центральними та регіональними органами державної влади.

Лазор О.Я. стверджував, що управління в галузі екології та природних ресурсів означає вплив суспільства на довкілля, зокрема на його охорону, раціональне використання та відтворення, а управління як процес у сфері екології та природних ресурсів означає правомірність відповідних інституцій: державних, самоврядних та громадських - здійснювати законодавчі, організаційнорозпорядчі, координаційні, представницькі і контрольні функції [11].

Якщо розглядати державне управління у сфері реалізації екологічної політики з позицій системного аналізу, то суб'єкти управління (державні органи та органи місцевого самоврядування) та об'єкти управління (підвідомчі сфери управління) взаємодіють через управлінську діяльність. Для всіх систем управління характерна наявність таких невід'ємних складових частин і елементів, як суб'єкт управління, об'єкт управління, управлінський вплив і зворотний зв'язок, що утворюють єдиний і водночас загальний контур управління. У свою чергу, роль і місце державного екологічного управління на різних рівнях владних структур зумовлені характером завдань, які вирішуються на кожному рівні. У процесі функціонування відбувається їх взаємодія по горизонталі і вертикалі, а регулятором цієї взаємодії $є$ нормативно-правова база держави.

У процесі формування та реалізації державної екологічної політики використовуються також заходи природоохоронного спрямування, економічне регулювання і стимулювання природоохоронної діяльності, спонукальні заходи i, врешті, примусові заходи. Основними методами реалізації екологічної політики, спрямованими на захист навколишнього середовища, регулювання природокористування, забезпечення екологічної безпеки країни, належать економічні (у постаті кредитів, позик, інвестицій, податків, санкцій, податкових пільг на прибутки від природоохоронної діяльності, пільгових тарифів на очищення і перероблення промислових та побутових відходів). Врешті, задля досягнення цілі щодо формування в суспільних екологічних цінностей і засад сталого споживання та виробництва неодмінно використовуватимуться просвітницькі та освітньо-інформаційні заходи та методи інформування, що 
реалізуються за допомогою інструменту екологічних комунікацій, у тому числі і з використанням засобів масової інформації та реклами.

Державна екологічна політика - це складова політики держави, що віддзеркалює сукупність її цілей і завдань у сфері екології, які формуються політичною системою держави відповідно до ії соціального призначення і реалізуються нею за допомогою певних механізмів. До механізмів формування та реалізації державної екологічної політики належать правовий, економічно-фінансовий, інформаційнокомунікаційний, інституційний тощо. У частині цього дослідження здійснено спробу побудови правового механізму формування та реалізації державної екологічної політики (рис. 1).

Процес формування та реалізації екологічної політики починається 3 ідентифікації екологічних проблем на відповідних рівнях, адже екологічні проблеми як і інші суспільні проблеми можуть досягати глобальних масштабів та потребувати спільного рішення відповідних держав. 3 етапу ідентифікації проблеми, в процесі формування та реалізації політики, вони аналізуються з позицій пошуку причиннаслідку та відповідного варіанта їх вирішення, що в сукупності обумовлює вибір альтернативного варіанта та впровадження відповідної екологічної політики. Впровадження обраного варіанта політики відбувається майже одночасно із процесом моніторингу стану та ситуації в екологічній сфері та сфері охорони навколишнього середовища 3 подальшим коригуванням політики, у разі ідентифікації нових екологічних проблем, або ж прийняття рішення щодо продовження обраного варіанта. У свою чергу, результатом процесу політики є конкретний напрям дій на відповідному рівні: наднаціональному, державному та суб'єктному.

Екологічна політика на наднаціональному рівні - це політика, що формується та реалізується міжнародними спільнотами, об’єднаннями країн та організаціями. Визначальне місце у процесі формування та реалізації екологічної політики в Україні серед суб'єктів наднаціонального рівня займають ООН, Саміт сталого розвитку та Європейський Союз. Це не є вичерпним переліком суб'єктів формування та реалізації екологічної політики на наднаціональному рівні, однак вплив їх діяльності на визначення векторів національної екологічної політики України є помітним на сучасному етапі, під час ратифікації міжнародних договорів, угод, конвенцій, директив тощо.

Екологічна політика на державному рівні - це політика, що комплексно формується та реалізується органами державної влади України у межах та відповідно до стратегічних цілей та пріоритетів, визначених вищим політичним керівництвом.

Екологічна політика на суб'єктному рівні - це діяльність суб'єктів господарювання або інших економічних одиниць, що проявляється у задекларованих внутрішніх засадах та визначених екологічних межах провадження їх діяльності. Слід зауважити, що суб'єкти господарювання одночасно формують та реалізують державну екологічну політику, а також впливають на формування та реалізацію екологічної політики на наднаціональному рівні (зазвичай, це транснаціональні компанії) шляхом провадження інноваційної діяльності, що дозволяє мінімізувати екологічні наслідки та в результаті досягти позитивного екологічної ефекту. У сучасних умовах транснаціональні компанії та інші великі гравці на міжнародному ринку, особливо це стосується європейських компаній, є впливовими лобістами, важливим елементом діяльності яких є налагодження співпраці з органами влади (наднаціонального рівня, наприклад, Свропарламентом) щодо формування та реалізації відповідної політики, у тому числі, i екологічної.

Використання правового регулювання як інструменту політики на кожному із визначених рівнів та їх взаємодія із іншими інструментами та елементами екологічної політики обумовлюватиме правовий механізм формування та реалізації цієї політики. Правове регулювання як інструмент екологічної політики, у свою чергу, деталізується у вигляді угод, конвенцій, договорів тощо на наднаціональному рівні; стратегій, планів дій, концепцій, законів, підзаконних актів тощо - на державному рівні; екологічна політика як внутрішній документ окремого суб'єкта господарювання - на суб'єктному рівні. 


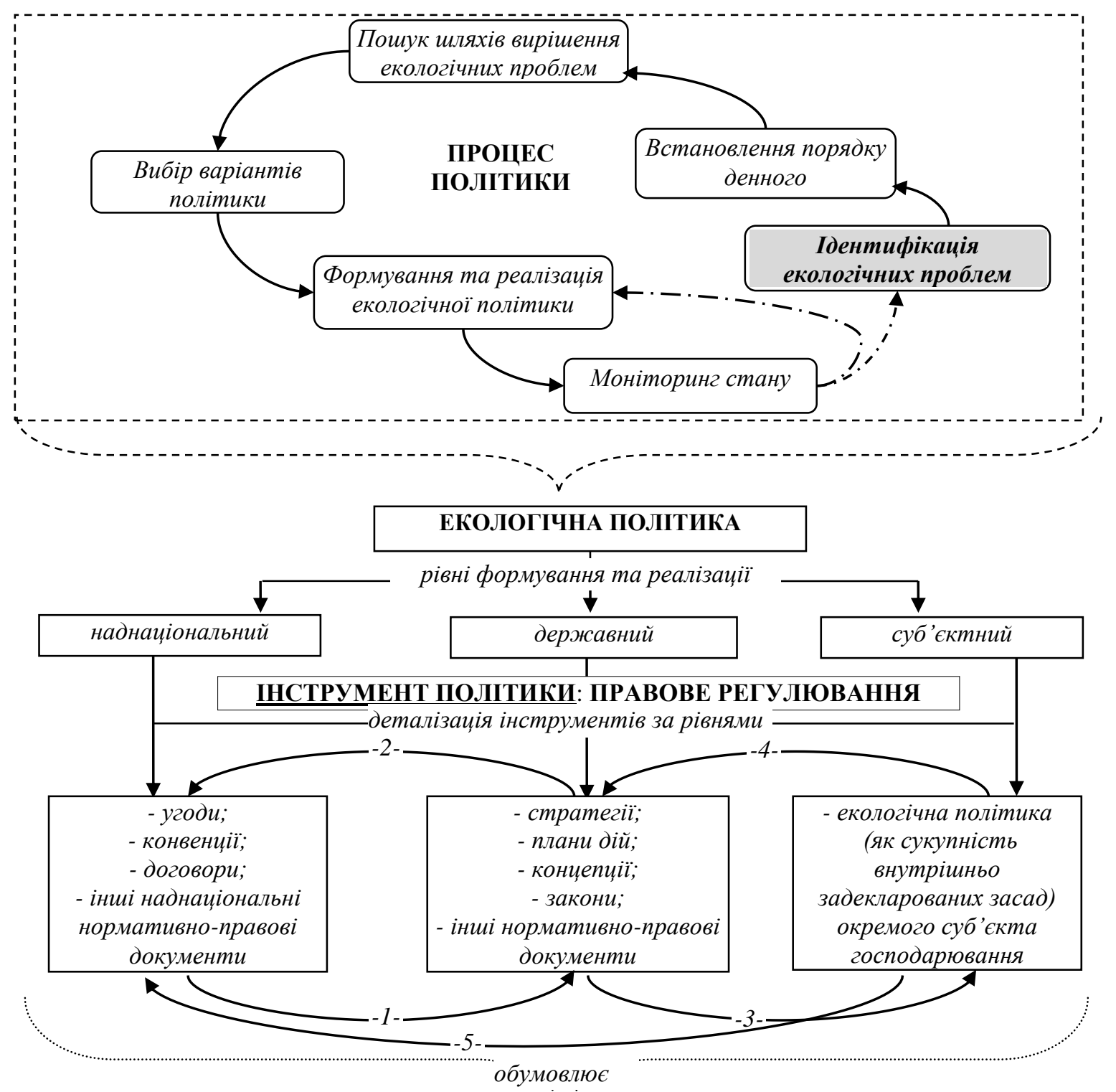

ПРАВОВИЙ МЕХАНІЗМ

\section{Зміст взаємодії інструментів між рівнями:}

1 -вплив на формування; визначення основоположних засад; встановлення пріоритетів;

2 - створення/забезпечення нормальних умов функиіонування сфер (об'єктів регулювання); адаптація до вимог та засад; долучення до прочесу реалізаиії;

3 - вплив на формування/реалізацію екологічної політики суб'єкта; встановлення законодавчих меж; визначення пріоритетів;

4 -забезпечення прочесу реалізачіi державноі екологічної політики;

5 - вплив (ТНК) на формування/реалізацію екологічноі політики; долучення до процесу иляхом лобіювання комериійних інтересів; розвиток та імплементація інновачійних підходів до вирішення екологічних проблем задля побудови позитивного іміджу екологічно відповідальних компаній

Рис. 1. Правовий механізм формування та реалізації державної екологічної політики

\section{Критерії взаємодіï}

інструментів міжс рівнями: - актуальність;- доиільність;

- законність; - гнучкість;

- результативність; - ефективність; - справедливість;

- верховенства права;

- иілісність та узгодженість 
Зміст взаємодії між рівнями формування та реалізації екологічної політики, у контексті правового механізму екологічної політики, свідчить про взаємовплив та взаємодію кожного із рівнів у процесі політики, яка обов'язково має грунтуватися на таких критеріях:

- актуальності, тобто засади формування та реалізації політики на відповідних рівнях мають бути актуальними та відповідати вимогам часу;

- доиільності, адже сформовані засади політики, а також імплементація деяких положень або ж адаптація національної політики до міжнародних норм мають відповідати вітчизняному стану, особливостям та реаліям екологічної сфери;

- законності, тобто взаємовплив на формування та реалізацію екологічної політики має здійснюватися в межах чинного законодавства, у законодавчо визначений спосіб та із використанням відповідних методів та інструментів державного управління;

- гнучкості, адже процес формування та реалізація політики не має закінченого циклу та потребує постійного коригування до відповідних змін зовнішнього та внутрішнього середовища;

- результативності, коли процес політики передбачає досягнення визначених результатів;

- ефективності, тобто ресурсів, які витрачаються для реалізації відповідного обраного варіанта політики, має бути задіяно менше, аніж отриманого результату;

- справедливості як основоположного принципу здійснення державного управління та взаємодії держави та суспільства;

- верховенства права, адже прийняття будь яких державно-управлінських дій, формування та реалізація екологічної політики, а також взаємодія між рівнями екологічної політики має здійснюватися в усвідомленні, ототожненні та дотриманні прав та свобод людини і громадянина як найвищої соціальної цінності;

- цілісності та узгодженості, зважаючи на те, що екологічна політика є невід'ємним елементом цілісної діяльності держави, в тому числі і в процесі ії формування та реалізації, виникає необхідність узгодження положень та засад політики з іншими сферами життєдіяльності та об'єктами державного управління.

Ідентифікацію критеріїв здійснено з метою визначення меж, що визначатимуть позитивний ефект взаємодії між рівнями застосування правового регулювання як інструменту політики, у досягненні екологічних цілей, в процесі правового механізму формування та реалізації екологічної політики.

Висновки 3 цього дослідження. Людина як частина природи має певні екологічні права і обов'язки, насамперед право на гармонійне довкілля. Однак технологічне навантаження на природне середовище погіршує умови проживання людини, що потребує відповідного інструменту вирішення екологічних проблем та поліпшення ситуації в Україні та світі. Формування та реалізація виваженої довгострокової екологічної політики суб'єктами на різних рівнях за допомогою сукупності методів, засобів та інструментів державно-управлінського впливу відіграє важливу роль у забезпеченні екологічного добробуту суспільства.

Екологічна політика - це визначений державою напрям дій, що базується на сукупності нормативноправових норм, використанні заходів, засобів та інструментів державного управління 3 метою забезпечення збалансування інтересів стейкхолдерів шляхом визначення цілей у сфері раціонального природокористування, охорони навколишнього середовища і забезпечення екологічної безпеки, на основі моніторингу стану та ситуації щодо показників екологічного середовища та його впливу на здоров'я населення, збільшення тривалості життя, відтворення рослинного і тваринного світу, збереження екологічної, генетичної і матеріальної основи життя, а також історичної спадщини i культури.

Особливістю держави як політичного інституту є прерогатива на використання правових норм (створення, реалізація і контроль за їх дотриманням). Правове регулювання є важливим інструментом формування та реалізації державної екологічної політики та основою іï правового механізму. Під час дослідження було візуалізовано правовий механізм формування та реалізації державної екологічної політики із визначенням рівнів політики (наднаціональний, державний, суб'єктний) та ідентифікацією взаємозв'язків між рівнями політики. Охарактеризовано зміст взаємодії між рівнями формування та реалізації екологічної політики й обгрунтовано критерії взаємодії інструментів між зазначеними рівнями (актуальність; доцільність; законність; гнучкість результативність; ефективність; справедливість; верховенства права; цілісність та узгодженість).

\section{Список використаної літератури:}

1. Андрієнко М.В. Сутність державної екологічної політики на загальнодержавному та регіональних рівнях / M.B. Андрієнко, В.С. Шако // Державне управління: удосконалення та розвиток. - 2016. - № 9 [Електронний pecypc]. - Режим доступу : http://www.dy.nayka.com.ua/?op=1\&z=1051.

2. Ветвицький Д.О. Розвиток державної екологічної політики України в умовах глобалізації : автореф. дис. ... канд. наук $з$ держ. упр. : 25.00 .02 / Д.О. Ветвицький ; Акад. муніцип. упр. - К., 2010. - 20 с. 
3. Водний кодекс України : Закон України № 213/95-ВР від 6 черв. 1995 р. [Електронний ресурс]. - Режим доступу : http://zakon4.rada.gov.ua/laws/show/213/95-вр.

4. Закон України «Про Основні засади (стратегію) державної екологічної політики України на період до 2020 року» від 21 грудня 2010 року № 2818-VI // Верховна Рада України [Електронний ресурс]. - Режим доступу : https://zakon.rada.gov.ua/laws/show/2818-17.

5. Закон України «Про Основні засади (стратегію) державної екологічної політики України на період до 2030 року» від 28.02.2019 № 2697-VIII // Верховна Рада України [Електронний ресурс]. - Режим доступу : https://zakon.rada.gov.ua/laws/show/2697-19.

6. Закон України «Про охорону навколишнього природного середовища» від 25.06.1991 № 1264-XII [Електронний ресурс]. - Режим доступу : http://zakon3.rada.gov.ua/laws/show/1264-12.

7. Земельний кодекс України : Закон України № 2768-III від 25 жовтня 2001 р. - Режим доступу : http://zakon4.rada.gov.ua/laws/show/2768-14.

8. Кодекс України про надра: Кодекс № 132/94-ВР від 27 липня 1994 р. [Електронний ресурс]. - Режим доступу : http://zakon4.rada.gov.ua/laws/show/132/94-\%D0\%B2\%D $1 \% 80$.

9. Кодекс цивільного захисту України : закон України № 5403-VI від 2 жовтня 2012 р. [Електронний ресурс]. Режим доступу : http:/ /zakon4.rada.gov.ua/laws/show/5403-17.

10. Конституція України : Закон України від 28.06.1996 № 254к/96-ВР [Електронний ресурс]. - Режим доступу : http: //zakon2.rada.gov.ua/laws/show/254к/96-вр.

11. Лазор О.Я. Державне управління у сфері реалізації екологічної політики в Україні: організаційно-правові засади : монографія / О.Я. Лазор. - Л. : Ліга-Прес, 2003. - 542 с.

12. Лісовий кодекс України : Закон України № 3404-IV від 8 лютого 2006 р. [Електронний ресурс]. - Режим доступу : http://zakon4.rada.gov.ua/laws/show/3852.

13. Малиш Н.А. Ефективні механізми формування державної екологічної політики : монографія / Н.А. Малиш. K. : K.I.C., 2011. - 348 c.

14. Місія та стратегія Міністерства екології та природних ресурсів // Офіційний портал Міністерства екології та природних ресурсів. - 2019 [Електронний ресурс]. - Режим доступу : https://menr.gov.ua/content/misiya-tastrategiya.html.

15. Мягченко О.П. Основи екології : підруч. для вищ. навч. закладів / О.П. Мягченко. - К. : Центр учбової літератури, 2010. - $312 \mathrm{c}$

16. Постанова Верховної Ради України «Про Основні напрями державної політики України у галузі охорони довкілля, використання природних ресурсів та забезпечення екологічної безпеки» від 05.03.1998 № 188/98ВР // Верховна Рада України [Електронний ресурс]. - Режим доступу : https://zakon3.rada.gov.ua/laws/show/188/98-\%D0\%B2\%D1\%80.

17. Сахаєв В.Г. Економіка і організація охорони навколишнього середовища : підручник / В.Г. Сахаєв, В.Я. Шевчук. - К. : Вища школа, 1995. - 272 с.

\section{References:}

1. Andrijenko, M.V. and Shako, V.S. (2016), Sutnist' derzhavnoi' ekologichnoi' polityky na zagal'noderzhavnomu ta regional'nyh rivnjah», Derzhavne upravlinnja: udoskonalennja ta rozvytok, No. 9, [Online], available at: http://www.dy.nayka.com.ua/?op=1\&z=1051

2. Vetvyc'kyj, D.O. (2010), Rozvytok derzhavnoi' ekologichnoi' polityky Ukrai'ny v umovah globalizacii', Abstract of Ph.D. dissertation, 25.00.02, Akad. municyp. upr., K., 20 p.

3. Verhovna Rada Ukrai'ny (1995), Vodnyj kodeks Ukrai'ny, Zakon Ukrai'ny, No. 213/95-VR, [Online], available at: http://zakon4.rada.gov.ua/laws/show/213/95-vr

4. Verhovna Rada Ukrai'ny (2010), Pro Osnovni zasady (strategiju) derzhavnoi' ekologichnoi' polityky Ukrai'ny na period do 2020 roku, Zakon Ukrai'ny, No. 2818-VI, [Online], available at: https://zakon.rada.gov.ua/laws/show/2818-17

5. Verhovna Rada Ukrai'ny (2019), Pro Osnovni zasady (strategiju) derzhavnoi' ekologichnoi' polityky Ukrai'ny na period do 2030 roku, Zakon Ukrai'ny, No. 2697-VIII, [Online], available at: https://zakon.rada.gov.ua/laws/show/2697-19

6. Verhovna Rada Ukrai'ny (1991), Pro ohoronu navkolyshn'ogo pryrodnogo seredovyshha, Zakon Ukrai'ny, No. 1264-XII, [Online], available at: http://zakon3.rada.gov.ua/laws/show/1264-12

7. Verhovna Rada Ukrai'ny (2001), Zemel'nyj kodeks Ukrai'ny, Zakon Ukrai'ny, No. 2768-III, [Online], available at: http://zakon4.rada.gov.ua/laws/show/2768-14

8. Verhovna Rada Ukrai'ny (1994), Kodeks Ukrai'ny pro nadra, No. 132/94-VR, [Online], available at: http://zakon4.rada.gov.ua/laws/show/132/94-\%D0\%B2\%D $1 \% 80$

9. Verhovna Rada Ukrai'ny (2012), Kodeks cyvil'nogo zahystu Ukrai'ny, No. 5403-VI, [Online], available at: http://zakon4.rada.gov.ua/laws/show/5403-17

10. Verhovna Rada Ukrai'ny (1996), Konstytucija Ukrai'ny, Zakon Ukrai'ny, No. 254k/96 VR, [Online], available at: http: //zakon2.rada.gov.ua/laws/show/254k/96 vr

11. Lazor, O.Ja. (2003), Derzhavne upravlinnja u sferi realizacii' ekologichnoi' polityky v Ukrai'ni: organizacijnopravovi zasady, monografija, Liga-Pres, L., 542 p.

12. Verhovna Rada Ukrai'ny (2006), Lisovyj kodeks Ukrai'ny, No. 3404-IV, [Online], available at: http://zakon4.rada.gov.ua/laws/show/3852

13. Malysh, N.A. (2011), Efektyvni mehanizmy formuvannja derzhavnoi' ekologichnoi' polityky, monografija, K.I.S., K., $348 \mathrm{p}$. 
14. «Misija ta strategija Ministerstva ekologii' ta pryrodnyh resursiv» (2019), Oficijnyj portal Ministerstva ekologii' ta pryrodnyh resursiv, [Online], available at: https://menr.gov.ua/content/misiya-ta-strategiya.html

15. Mjagchenko, O.P. (2010), Osnovy ekologii', pidruch. dlja vyshh. navch. zakladiv, Centr uchbovoi' literatury, K., $312 \mathrm{p}$.

16. Verhovna Rada Ukrai'ny (1998), Pro Osnovni naprjamy derzhavnoi' polityky Ukrai'ny u galuzi ohorony dovkillja, vykorystannja pryrodnyh resursiv ta zabezpechennja ekologichnoi' bezpeky, Postanova, No. 188/98-VR, [Online], available at: https://zakon3.rada.gov.ua/laws/show/188/98-\%D0\%B2\%D1\%80

17. Sahajev, V.G. and Shevchuk, V.Ja. (1995), Ekonomika i organizacija ohorony navkolyshn'ogo seredovyshha, pidruchnyk, Vyshha shkola, K., $272 \mathrm{p}$.

Сергіснко Лариса Василівна - кандидат наук з державного управління, доцент кафедри економічної безпеки, публічного управління та адміністрування Державного університету «Житомирська політехніка».

Наукові інтереси:

- механізми державного управління за галузями;

- державна економіко-екологічна політика.

Дзюбенко Олег Миколайович - кандидат економічних наук, доцент кафедри економічної безпеки, публічного управління та адміністрування Державного університету «Житомирська політехніка».

Наукові інтереси:

- формування та реалізація державної екологічної політики;

- управління лісогосподарськими підприємствами.

Ожго Світлана Вітауто - магістрант гр. ЗДУм-18-3м Державного університету «Житомирська політехніка», головний спеціаліст-бухгалтер відділу бухгалтерського обліку і контролю департаменту фінансів Житомирської обласної державної адміністрації.

Наукові інтереси:

- реалізація державної політики у сфері публічних закупівель;

- бухгалтерський облік і контроль доходів і видатків у загальнодержавному секторі.

Стаття надійшла до редакції 19.07.2019. 